Situs Jurnal : http://ejournal.stiepancasetia.ac.id/index.php/jieb

Jilid 5 Nomor 2 Juli 2019

Hal $227-237$

\title{
ANALISIS PENGARUH KUALITAS PELAYANAN DAN PROMOSI TERHADAP KEPUTUSAN PEMBELIAN PADA MERCHANT GO FOOD FESTIVAL DUTA MALL BANJARMASIN
}

\author{
Muhammad Iqbal*, Abdul Kadir*
}

Abstrak : Muhammad iqbal, Jurusan Manajemen Sekolah Tinggi Ilmu Ekonomi Pancasetia Banjarmasin, 2020, Analisis Pengaruh Kualitas Pelayanan dan Promosi terhadap Keputusan Pembelian GoFood Festival Duta Mall Banjarmasin Pembimbing 1: Abdul kadir, Pembimbing 2 : Firda Nosita. Penelitian ini bertujuan untuk mengetahui Pengaruh Kualitas pelayanan dan Promosi simultan maupun parsial terhadap Keputusan Pembelian GoFood Festival. Jenis penelitian yang digunakan adalah penelitian korelasional. Tujuan penelitian korelasional adalah untuk mengidentifikasi hubungan prediktif dengan menggunakan teknik korelasi atau teknik statistik, dengan sampel sebanyak 100 orang. Dan teknik analisis data dengan uji regresi linear berganda. Hasil penelitian menunjukan Kualitas pelayanan dan Promosi berpengaruh signifikan secara simultan terhadap keputusan pembelian pada Merchant GoFood Festival Duta Mall Banjarmasin. Variabel Kualitas Pelayanan dan Promosi juga berpengaruh secara parsial terhadap keputusan pembelian pada Merchant GoFood Festival Duta Mall Banjarmasin. Sedangkan variabel yang dominan berpengaruh terhadap Keputusan Pembelian adalah Kualitas Pelayanan.

Kata Kunci : Kualitas Pelayanan, Promosi, Keputusan Pembelian, GoFood Festival.

Abstract : Muhammad Iqbal, Management Department of Pancasetia School of Economics Banjarmasin, 2020, Analysis of the Effect of Service Quality and Promotion on Purchasing Decisions of GoFood Festival Banjarmasin Mall Ambassador Supervisor 1: Abdul Kadir, Advisor 2: Firda Nosita. This study aims to study the effect of simultaneous and partial service quality and promotion on GoFood Festival Purchasing Decisions. The type of research used is correlational research. The purpose of correlational research is to examine predictive relationships using comparison techniques or statistical techniques, with a sample of 100 people. And data analysis techniques with multiple linear regression tests. The results showed the quality of service and promotion of significant importance to the purchasing decisions at the GoFood Festival Duta Mall Banjarmasin Merchant. Service Quality and Promotion Variables also apply partially to purchasing decisions at the Duta Mall Banjarmasin GoFood Merchant Festival. While the dominant variable influencing the Purchasing Decision is Service Quality.

Keywords: Service Quality, Promotion, Purchasing Decisions, GoFood Festival.

*Sekolah Tinggi Ilmu Ekonomi Pancasetia 


\section{PENDAHULUAN}

\section{Latar Belakang Masalah}

Penggunaan internet tidak hanya terbatas pada pemanfaatan informasi yang dapat diakses melalui media ini, melainkan juga dapat digunakan sebagai sarana untuk melakukan transaksi perdagangan yaitu melalui electronic commerce.

Berdasarkan hasil survei APJII tahun 2018 dan Polling Indonesia jumlah pengguna internet di Indonesia pada 2018 bertambah 27,91 juta $(10,12 \%)$ menjadi 171,18 juta jiwa. Artinya penetrasi pengguna internet di tanah air meningkat menjadi $64,8 \%$ dari total penduduk yang mencapai 264,16 juta jiwa. Sementara berdasarkan spasial, Jawa masih menjadi wilayah pengguna internet terbesar di Indonesia, yakni mencapai 55\%. Adapun pengguna internet terbesar berikutnya adalah Sumatera (21\%), Kalimantan (9\%). diikuti Sulawesi, Maluku dan Papua (10\%) serta Bali dan Nusa Tenggara (5\%).

Terobosan baru dimunculkan oleh para pengusaha muda yang mengembangkan inovasi baru dalam penyediaan jasa transportasi online, yaitu ojek online. Belakangan ini beberapa aplikasi ojek online berhasil merebut pasar, seperti GoJek, Grab, Uber, Maxim. Aplikasi GoJek telah melekat di benak masyarakat, dan belakangan PT GoJek Indonesia mulai memiliki kompetitor aplikasi GoJek telah melekat di benak masyarakat, dan belakangan PT GoJek Indonesia mulai memiliki kompetitor terkuatnya yaitu Grab. GoJek (sebelumnya ditulis GO-JEK) merupakan sebuah perusahaan teknologi asal Indonesia yang melayani angkutan melalui jasa ojek. Perusahaan ini didirikan pada tahun 2010 di Jakarta oleh Nadiem Makarim.

PT GoJek Indonesia sebagai perusahaan pionir yang menggagas jasa transportasi ojek online mampu merebut pangsa pasar terbukti hanya dalam kurun waktu tiga bulan layanan GoJek telah diunduh sebanyak 100.000 kali. Pada Januari 2015, aplikasi ini diunduh sebanyak 32.360 kali, pada Februari 81.843 kali dan Maret 131.795 kali pada Tahun 2018 Aplikasi GoJek telah diunduh lebih dari 125 juta kali oleh pengguna Desember 2018 ( Wardani, 2019)
PT GoJek Indonesia memberikan layanan berbasis pada aplikasi GoJek yang dapat diunduh secara gratis pada masing-masing ponsel calon penggunanya. Dalam aplikasi nya, PT GoJek Indonesia menawarkan berbagai macam layanan, mulai dari antar jemput dengan motor (GoRide) atau mobil (GoCar), mengirim barang (GoSend), membantu pemindahan barang antar wilayah (GoBox), hingga layanan pembelian makanan atau minuman (GoFood).

Kualitas pelayanan yang ditawarkan oleh keduanya cenderung sama karena sistem pelayanan konsumen yang diterapkan hampir sama. Yaitu dalam pemesanan makanan, pengantaran makanan pada konsumen, dan bukti fisik pelayanan. Kemudian pada kegiatan promosinya kedua usaha ini juga sedikit dan jarang dilakukan. Kendati demikian, kedua usaha kuliner ini tetap berjalan hingga saat ini.

Dengan adanya persaingan ini, GoFood Festival Banjarmasin dituntut untuk dapat mengerti apa yang menjadi keinginan atau harapan konsumen agar tercipta kepuasan bagi konsumennya supaya pelanggan tidak kecewa dan membeli produk pesaing. Dengan demikian kualitas pelayanan yang diberikan oleh pihak pengelola GoFood festival akan dapat memberikan kepuasan tersendiri bagi konsumennya. Penelitian ini menguji Pengaruh Kualitas pelayanan dan Promosi terhadap Keputusan pembelian pada merchant GoFood Festival Duta Mall Banjarmasin.

Selain memudahkan konsumen, fitur GoFood ini juga menjadi alternatif bagi pengusaha kuliner, baik usaha mikro hingga menengah yang memiliki modal terbatas dalam mengembangkan layanan pesan-antarnya, untuk bekerja sama dengan PT Gojek Indonesia dan dapat memperluas pangsa pasarnya. Jika pangsa pasar meningkat, maka tentu permintaan akan meningkat, kemudian jumlah produk yang dihasilkan juga harus meningkat, termasuk juga tenaga produksi akan meningkat.

GoFood sebagai layanan pesan-antar makanan dalam aplikasi GoJek, kembali menegaskan komitmennya mendukung usaha mikro, kecil dan menengah (UMKM) kuliner untuk meningkatkan skala bisnisnya melalui GoFood Festival yang kini hadir di Duta Mall Banjarmasin. 


\section{Rumusan Masalah}

1. Apakah Kualitas pelayanan dan Promosi berpengaruh signifikan secara simultan terhadap keputusan pembelian GoFood Festival ?

2. Apakah Kualitas pelayanan berpengaruh signifikan secara parsial terhadap keputusan pembelian GoFood Festival?

3. Apakah Promosi berpengaruh signifikan secara parsial terhadap keputusan pembelian GoFood Festival ?

4. Diantara dua variabel Kualitas pelayanan dan Promosi, Variabel manakah yang berpengaruh secara dominan terhadap Keputusan Pembelian GoFood Festival ?

\section{Tujuan Penelitian}

1. Untuk mengetahui apakah Kualitas pelayanan dan Promosi berpengaruh signifikan secara simultan terhadap keputusan pembelian GoFood Festival.

2. Untuk mengetahui apakah Kualitas pelayanan berpengaruh signifikan secara parsial terhadap keputusan pembelian GoFood Festival

3. Untuk mengetahui apakah Promosi berpengaruh signifikan secara parsial terhadap keputusan pembelian GoFood Festival.

4. Untuk mengetahui apakah Variabel yang berpengaruh dominan diantara Kualitas Pelayanan dan Promosi terhadap Keputusan Pembelian GoFood Festival.

\section{TINJAUAN PUSTAKA}

\section{Pengertian Pemasaran}

Menurut Kotler dan Keller (dalam Aditya dwi nugraha, 2014) Pemasaran adalah proses, cara, perbuatan dalam memasarkan barang dagangan, dan menyebarluaskan di masyarakat. Pada dasarnya pemasaran merupakan suatu proses sosial dan manajerial dimana individu dan kelompok mendapatkan yang mereka butuhkan dan inginkan melalui penciptaan dan pertukaran produk dan nilai dengan yang. American Marketing Association merumuskan definisi pemasaran yang lebih menekankan pada proses manajerial, yaitu proses perencanaan dan penetapan konsepsi, penetapan harga, promosi, dan distribusi gagasan, barang dan jasa untuk menciptakan pertukaran yang memuaskan tujuan individu dan organisasi. Adapun American Marketing Association (AMA) menjelaskan pemasaran sebagai berikut :

"Pemasaran adalah suatu fungsi organisasi dan serangkaian proses untuk menciptakan, mengomunikasikan, dan memberikan nilai kepada pelanggan dan untuk mengelola hubungan pelanggan dengan cara yang menguntungkan organisasi dan pemangku kepentingannya." (Kotler \& Keller, 2014).

1.Social Media Marketing

Kemunculan beragam media sosial tidak hanya menguntungkan individu, melainkan juga para pelaku bisnis. Media sosial bisa dimanfaatkan untuk memasarkan produk hingga berinteraksi dengan konsumen. Kunci dari kesuksesan social media marketing tidak lain adalah konten yang menarik. Sehingga, jika dilakukan dengan tepat, penggunaan media sosial juga bisa berpengaruh pada reputasi perusahaan.

2.Email and Content Marketing

Manfaatkan fitur subscribe untuk mengumpulkan email calon konsumen yang tertarik dengan produk perusahaan. Apabila bisnis yang dijalankan memungkinkan publik untuk sign up dengan email, gunakan juga kesempatan ini untuk membuat strategi customer relationship management (CRM). CRM sendiri merupakan strategi menjaga hubungan dengan konsumen, bisa dengan mengirimkan newsletter berisi promo dan berita seputar produk perusahaan hingga menggunakan nomor telepon untuk menjangkau konsumen secara langsung. Selain menggunakan trik tersebut, perusahaan sekarang juga sudah beralih ke konten marketing dengan membuat blog yang berisikan informasi relevan terkait jenis usaha. Konten ini diharapkan bisa menarik konsumen dan meningkatkan awareness secara online.

3.Komunitas

Baik itu secara online maupun offline, perusahaan bisa mencoba meningkatkan loyalitas konsumen dengan membangun komunitas pengguna. Komunitas online bisa dibangun melalui media sosial ataupun forum yang ada di website perusahaan. Komunitas online ini juga bisa dimanfaatkan untuk menciptakan komunitas 
offline melalui kegiatan-kegiatan yang dibuat khusus bagi para anggotanya.

\section{Remarketing}

Strategi ini menargetkan iklan online kepada pengunjung website perusahaan. Misalnya, seseorang yang baru saja membuka website A kemungkinan besar akan mendapatkan iklan seputar produk A meskipun Ia sudah berada di website lain. Taktik ini bermanfaat untuk meningkatkan awareness, traffic, hingga penjualan.

\section{Pengetian Kualitas Pelayanan}

Kualitas pelayanan menurut (Kotler, 2013 :34) adalah sebuah kinerja yang dapat ditawarkan oleh seseorang kepada orang lain. Kinerja ini dapat berupa tindakan yang tidak berwujud serta tidak berakibat pada kepemilikan barang apapun dan terhadap siapapun.

Poin utamanya adalah pelayanan merupakan suatu tindakan yang dilakukan oleh seorang penjual kepada pembeli / konsumennya demi memenuhi kebutuhan dan keinginan konsumen. Perilaku tersebut bertujuan pada tercapainya kepuasan pelanggan itu sendiri.

Sebuah pelayanan dapat dilakukan pada saat konsumen memilih produk maupun setelah selesai melakukan transaksi pembelian produk. Kualitas pelayanan yang baik akan memberikan dampak yang baik pula bagi perusahaan karena akan menjadi pelanggan yang loyal dan memberikan keuntungan bagi perusahaan.

A.Dimensi - dimensi Kualitas Pelayanan

1.Bukti fisik (Tangible)

Bukti fisik merupakan suatu service yang bisa dilihat, bisa dicium dan bisa diraba, maka aspek tangible menjadi penting sebagai ukuran terhadap pelayanan. Bukti fisik suatu perusahaan dalam menunjukkan esksitensinya kepada pihak eksternal. Penampilan dan kemampuan sarana dan prasarana fisik perusahaan dan keadaan lingkungan sekitarnya adalah bukti nyata dari pelayanan yang diberikan oleh pemberi jasa yang meliputi fasilitas fisik perlengkapan, pegawai, dan sarana komunikasi. Tangible yang baik akan mempengaruhi persepsi pelanggan.

2.Kehandalan (Reliability)

Reliability merupakan kemampuan perusahaan untuk melaksanakan jasa sesuai dengan apa yang telah dijanjikan secara tepat waktu. Pentingnya dimensi ini adalah kepuasan konsumen akan menurun bila jasa yang diberikan tidak sesuai dengan yang dijanjikan. Jadi komponen atau unsur dimensi reliability ini merupakan kemampuan perusahaan dalam menyampaikan jasa secara tepat dan pembebanan biaya secara tepat.

3.Ketanggapan (Responsiveness)

Merupakan kemampuan perusahaan yang dilakukan langsung oleh karyawan untuk memberikan pelayanan dengan cepat dan tanggap. Daya tanggap dapat menumbuhkan persepsi yang positif terhadap kualitas jasa yang diberikan. Termasuk didalamnya jika terjadi kegagalan atau keterlambatan dalam penyampaian jasa, pihak penyedia jasa berusaha memperbaiki atau meminimalkan kerugian konsumen dengan segera. Dimensi ini menekankan pada perhatian dan kecepatan karyawan yang terlibat untuk menanggapi permintaan, pertanyaan, dan keluhan konsumen. Jadi komponen atau unsur dari dimensi ini terdiri dari kesigapan karyawan dalam melayani pelanggan, kecepatan karyawan dalam melayani pelanggan dan penanganan keluhan pelanggan.

4.Jaminan (Assurance)

Merupakan pengetahuan dan perilaku employee untuk membangun kepercayaan dan keyakinan pada diri konsumen dalam mengkonsumsi jasa yang ditawarkan. Dimensi ini sangat penting karena melibatkan persepsi konsumen terhadap resiko ketidakpastian yang tinggi terhadap kemampuan penyedia jasa. Perusahaan membangun kepercayaan dan kesetiaan konsumen melalui karyawan yang terlibat langsung menangani konsumen. Jadi komponen dari dimensi ini terdiri dari kompotensi karyawan yang meliputi ketrampilan, pengetahuan yang dimiliki karyawan untuk melakukan pelayanan dan kredibilitas perusahaan yang meliputi hal-hal yang berhubungan dengan kepercayaan konsumen kepada perusahaan seperti, reputasi perusahaan, prestasi dan lain-lain.

5.Empati (Empathy)

Merupakan kemampuan perusahaan yang dilakukan langsung oleh karyawan untuk memberikan perhatian kepada konsumen secara individu, termasuk juga kepekaan atau kebutuhan konsumen. Jadi komponen dari dimensi ini merupakan gabungan dari akses (access) yaitu 
kemudahan untuk memanfaatkan jasa yang ditawarkan oleh perusahaan.

\section{Pengertian Promosi}

Menurut Tjiptono (2012: 219), pada hakekatnya promosi adalah suatu bentuk komunikasi pemasaran. Adapun yang dimaksud dengan komunikasi pemasaran adalah aktivitas pemasaran yang berusaha menyebarkan informasi, mempengaruhi atau membujuk, dan/atau mengingatkan pasar sasaran atas perusahaan dan produknya agar bersedia menerima, membeli, dan loyal pada produk yang ditawarkan perusahaan yang bersangkutan.

Selanjutnya Kotler (2013:41) menyatakan bahwa promosi adalah berbagai kegiatan yang dilakukan oleh perusahaan yang menonjolkan keistimewaan - keistimewaan produknya yang membujuk konsumen sasaran agar membelinya.

Menurut Tjiptono (2015: 222) tujuan promosi di antaranya adalah:

a.Menumbuhkan persepsi pelanggan terhadap suatu kebutuhan (category need).

b.Memperkenalkan dan memberikan pemahaman tentang suatu produk kepada konsumen (brand awareness).

c.Mendorong pemilihan terhadap suatu produk (brand attitude).

d.Membujuk pelanggan untuk membeli suatu produk (brand puchase intention).

e.Mengimbangi kelemahan unsur bauran pemasaran lain ( Puchase facilitation )

f.Menanamkan citra produk dan perusahaan (positioning).

Menurut Swastha dan Irawan (2014: 253) mengemukakan tujuan promosi adalah:

a.Modifikasi tingkah laku

Kegiatan promosi yang dilakukan sebagai usaha untuk merubah tingkat laku yang sudah ada. Penjualan akan selalu berusaha memberikan kesan baik pada produk yang dijualnya.

\section{b.Memberitahu}

Kegiatan promosi ditujukan untuk memberitahukan pasar yang dituju tentang penawaran perusahaan. Promosi yang bersifat informasi umumnya lebih sesuai dilakukan pada tahap-tahap awal di dalam siklus kehidupan produk. Kiranya hal ini merupakan masalah penting untuk meningkatkan permintaan. Sebagai orang tidak akan membeli barang atau jasa sebelum mereka mengetahui produk tersebut dan apa faedahnya. Promosi yang bersifat memberitahukan penting bagi konsumen karena dapat membantu pengambilan keputusan untuk membeli.

c.Membujuk

Promosi yang bersifat membujuk kurang disenangi orang namun kenyataan sekarang ini banyak yang muncul adalah promosi yang bersifat membujuk. Promosi seperti ini diarahkan untuk mendorong pembelian. Sering perusahaan tidak ingin memperoleh tanggapan secepatnya tetapi lebih mengutamakan untuk menciptakan kesan positif. Hal ini dimaksudkan agar dapat memberikan pengaruh dalam waktu lama terhadap perilaku pembeli.

d.Mengingatkan

Promosi yang bersifat mengingatkan, dilakukan untuk mempertahankan merek produk di hati masyarakat dan perlu dilakukan selama tahap kedewasaan di dalam siklus kehidupan produk. Ini berarti hak perusahaan berusaha untuk saling tidak mempertahankan pembeli yang ada. Jadi secara singkat promosi berkaitan dengan upaya bagaimana orang dapat mengenal produk perusahaan, lalu memahaminya berubah sikap, menyukai, dan yakin untuk membeli.

Menurut Tjiptono (2013:219), terdapat beberapa jenis promosi yang sering digunakan, yaitu:

a)Periklanan (Advertising)

Segala biaya yang harus dikeluarkan sponsor untuk melakukan persentasi dan promosi non pribadi dalam bentuk gagasan, barang atau jasa dengan mempromosikan pada iklan di televisi dan media massa.

b)Penjualan Personal (Personal Selling)

Persentasi pribadi oleh para wiraniaga perusahaan dalam rangka mensukseskan penjualan dan membangun hubungan dengan pelanggan.

c)Promosi Penjualan (Sales Promotion)

Insentif jangka pendek untuk mendorong pembelian atau penjualan suatu produk atau jasa.

d)Hubungan Masyarakat (Public Relation)

Membangun hubungan baik dengan publik terkait untuk memperoleh dukungan, membangun "citra perusahaan" yang baik dan menangani atau menyingkirkan gosip, cerita dan peristiwa yang dapat merugikan.

e)Pemasaran Langsung (Direct Marketing)

Pengertian Keputusan Pembelian 
Kotler dan Armstrong (2012:154) menyebutkan bahwa keputusan pembelian merupakan keputusan pembeli mengenai merek mana yang akan dibeli. Sebelum seseorang melakukan keputusan pembeli terlebih dahulu diawali oleh beberapa tahapan diantaranya problem recognition, information search, dan evaluation of alternatives, baru purchase decision yang dilanjutkan oleh post-purchase decision.

Proses pembelian terjadi ketika individu memahami permasalahan atau kebutuhan (problem recognition) yang ditimbulkan oleh stimulus yang berasal dari luar maupun dari dalam diri individu yang bersangkutan. Rangsangan-rangsangan tersebut dapat memicu kemungkinan individu untuk melakukan pembelian. Setelah individu menyadari adanya kebutuhan, maka individu akan sampai pada tahappencarian informasi (information search). Individu yang berada pada proses pencarian informasi dibedakan menjadi dua macam, yaitu:

1.Heightened attention adalah individu yang tidak berusaha mencari informasi tentang produk yang akan dibelinya;

2.Active information search adalah individu yang aktif mencari informasi tentang produk yang akan dibelinya. Selain itu, sumber informasi dapat juga dikelompokkan menjadi empat, yaitu:

a)Personal berupa informasi yang diperoleh dari keluarga, teman, tetangga atau kenalan yang lainnya;

b)Commercial berupa informasi yang diperoleh dari iklan, situs internet, sales, penyalur, pedagang, atau dari suatu pameran,;

c)Public berupa informasi yang diperoleh dari tv, koran atau radio;

d)Experiential berupa informasi yang diperoleh dari perlakuan, pengujian, atau penggunaan suatu produk secara langsung.

3.Tahap selanjutnya adalah evaluation of alternatives, yaitu proses dimana individu memilih produk mana yang memiliki banyak keunggulan atau manfaat bagi dirinya. Setelah individu membentuk pilihan terhadap suatu produk maka individu memutuskan untuk membeli (purchase decision) pada pilihannya dengan sub keputusan seperti pemilihan merek, penjual, jumlah barang, waktu pembelian, dan metode pembayaran. Setelah melakukan pembelian, maka individu akan dihadapkan pada post purchase decision dimana individu mengalami kepuasan atau ketidakpuasan. Konsumen yang merasa puas cenderung akan membeli lagi produk tersebut dan menceritakan kepada orang lain tentang keunggulan atau manfaat dari produk yang telah dibelinya itu, begitu sebaliknya dengan konsumen yang tidak puas atas suatu produk.

Pada saat seorang individu melakukan pembelian maka terdapat beberapa faktor yang mempengaruhi keputusan pembelian tersebut, diantaranya (Kotler dan Keller, 2012:151) adalah faktor budaya, sosial, pribadi, dan psikologis.

\section{Penelitian Terdahulu}

1. Armahadyani, 2015, Pengaruh Harga, Promosi dan Kualitas pelayanan terhadap keputusan pembelian konsumen pada kedai makan Pa,Mur Karawang. Metode yang digunakan dalam penelitian ini adalah metode kuantitatif, dan teknik analisis data yang digunakan adalah Analisis deskriftif, Analisis Verifikatif dan Koefesien Determinan. Hasil penelitian ini menunjuakan Pengaruh harga, Promosi dan Kualitas pelayanan memiliki pengaruh positif yang signifikan.

2. Novi Ariska, Tri Indra Wijaksana, 2016, Pengaruh Kualitas pelayanan dan Promosi penjualan terhadap minat beli ulang pada Konsumen Bakso Boedjangan Cabang burangrang Bandung, Metode yang digunakan dalam penelitian ini adalah metode Kuantitatif, dan Teknik Analisis yang digunakan adalah analisis Deskriptif, Analisis Regresi Linear Berganda, Pengujian Hipotesis, Analisis Koefisien Determinas. Hasil penelitian ini menunjukan Pengaruh Kualitas pelayanan dan promosi penjualan berpengaruh positif dan signifikan

3.Agung Tri Handoko, 2015, Analisis Kualitas pelayanan, Harga dan Promosi terhadap Keputusan pembelian pada Bamboo Café Lumajang, Teknik Analisis data yang digunakan adalah Uji Instrumen Data, Analisis Regresi Linier Berganda, Uji Asumsi Klasik, Uji Hipotesis, Hasil penelitian ini menunjukan Pengaruh Kualitas pelayanan, Harga dan Promosi sangat berpengaruh terhadap Keputusan pembelian pada Bamboo Café Lumajang.

\section{Kerangka Konseptual}




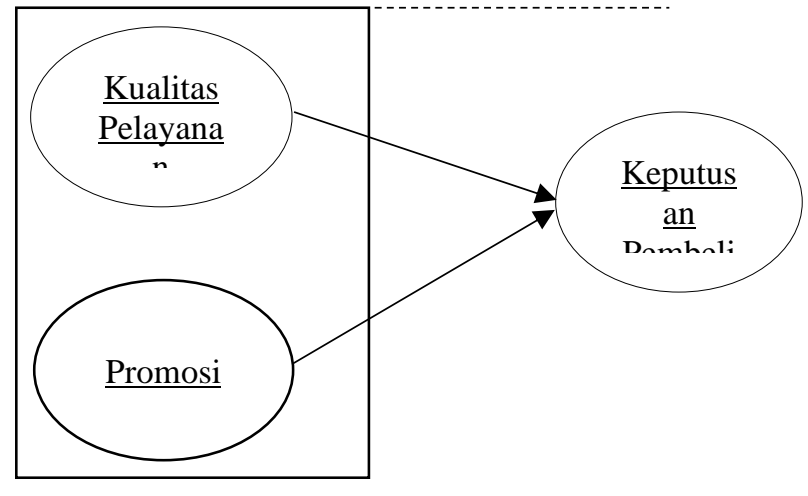

Keterangan :

Parsial :

Simultan : --------

\section{Hipotesis Penelitian}

H1 Kualitas pelayanan dan promosi berpengaruh signifikan secara simultan terhadap keputusan pembelian pada Go Food Festival

H2 Kualitas pelayanan berpengaruh signifikan secara parsial terhadap keputusan pembelian pada Go - Food Festival

H3 Promosi berpengaruh signifikan secara parsial terhadap keputusan pembelian pada Go - Food Festival

H4 Kualitas pelayanan lebih berpengaruh secara dominan terhadap keputusan pembelian Go - Food Festival

\section{METODE PENELITIAN}

Penelitian ini merupakan penelitian korelasional dengan pendekatan kuantitatif.

Populasi pada penelitian ini adalah adalah seluruh pelanggan GoFood Festival.

Sedangkan Sampel yang diambil pada penelitian ini berjumlah 100 orang responden
Jenis Data yang digunakan dalam penelitian ini adalah data Kuantitatif.

Adapun sumber data yang dikumpulkan dalam penelitian ini adalah data primer dan sekunder.

\section{Teknik Pengumpulan Data}

1) Kuesioner (Angket)

2) Library Research (Riset Kepustakaan)

\section{Definisi Operasional Variabel}

\section{Pengertian Kualitas Pelayanan ( X1 )}

Kualitas pelayanan menurut (Kotler, 2013) adalah sebuah kinerja yang dapat ditawarkan oleh seseorang kepada orang lain. Kinerja ini dapat berupa tindakan yang tidak berwujud serta tidak berakibat pada kepemilikan barang apapun dan terhadap siapapun. Indikator untuk mengukur promosi online mengacu pada pendapat Kotler, 2013, yaitu :

X1.1 Bukti fisik (tangible

X1.2 Kehandalan (reliability)

X1.3 Ketanggapan (responsiveness)

X1.4 Jaminan (assurance)

X1.5 Empati (empathy)

\section{Pengertian Promosi ( X2 )}

Menurut Tjiptono (2013:219), promosi merupakan salah satu penentu keberhasilan suatu program pemasaran. Betapa pun kualitasnya suatu produk, bila konsumen belum pernah mendengarnya dan tidak yakin bahwa produk itu akan berguna pada mereka, maka mereka tidak akan membelinya. Berikut ini adalah beberapa faktor yang dijadikan indikator pada penelitian ini, yaitu :

X2.1 Periklanan (Advertising)

X2.2 Promosi Penjualan ( Sales Promotion )

$\mathrm{X} 2.2 .1$ Kupon

X2.2.2 Hadiah ( Kontest, Undian, Permainan ) : X2.2.3 Penurunan harga

\section{Pengertian Keputusan Pembelian ( $Y$ )}

Pengambilan keputusan konsumen adalah proses pengitergasian yang mengkombinasikan pengetahuan untuk mengevaluasi dua atau lebih perilaku alternatif dan memiilih salah satu diantaranya (Setiadi, 2003 :16) Indikator yang dijadikan pada penelitian ini adalah : 
Y1 Minat beli ulang

Y2 Kepuasan Maksimal

Y3 Merekomendasikan kepada orang lain

\section{Teknik Analisis Data}

\section{Analisis Regresi Linier Berganda}

Teknik analisis yang digunakan dalam penelitian ini adalah regresi linier berganda. Teknik ini dipilih karena data yang ada berupa interval dan untuk mencari pengaruh antara variabel $\mathrm{X}$ dan $\mathrm{Y}$. Fungsi dari analisis regresi linier berganda penelitian ini digambarkan dalam bentuk persamaaan matematis sebagai berikut:

\section{Persamaan regresi}

Persamaan regresi dalam penelitian ini adalah

$\mathrm{Y}=\mathrm{a}+\mathrm{b} 1 \mathrm{x} 1+\mathrm{b} 2 \mathrm{x} 2+\mathrm{bx} \ldots \varepsilon$

Keterangan:

$\mathrm{Y}=$ keputusan pembelian online

$\mathrm{a}=$ konstanta

$\mathrm{b}=$ koefisien regresi

$\mathrm{X} 1=$ variabel promosi online

$\mathrm{X} 2$ = variabel harga

$\varepsilon=$ Standar error

\section{ANALISIS HASIL PENELITIAN DAN PEMBAHASAN}

\section{Hasil Uji Hipotesis}

\section{Analisis Regresi Linier Berganda}

Hasil output dari PSPP terhadap data skor yang telah dibuat berdasarkan jawaban responden dari kuesioner yang telah dibagikan kemudian dirangkum menjadi bahasan-bahasan sebagaimana yang terlihat pada tabel berikut :

\section{Hasil Regresi Linier Berganda}

\begin{tabular}{|ll|r|r|r|r|r|}
\hline \multirow{2}{*}{ Model } & \multicolumn{2}{|c|}{$\begin{array}{c}\text { Unstandardized } \\
\text { Coefficients }\end{array}$} & $\begin{array}{c}\text { Standardized } \\
\text { Coefficients }\end{array}$ & \multirow{2}{*}{$\mathrm{t}$} & \multirow{2}{*}{ Sig. } \\
\cline { 2 - 5 } & \multicolumn{1}{|c|}{ B } & Std. Error & \multicolumn{2}{c|}{ Beta } & & \\
\hline \multirow{2}{*}{ (Constant) } &,- 09 & 1.53 & &,- 06 & 0,952 \\
1 & .14 & .03 & .40 & 4,71 & 0,000 \\
& X1 & .20 & .05 & .35 & 4,11 & 0,000 \\
\hline
\end{tabular}

Sumber: Data diolah (2020)

Secara matematis model fungsi regresi linear berganda dapat dinyatakan sebagai berikut:

$\mathrm{Y}=-, 09+0,14 \cdot \mathrm{xI}+0,20 \cdot \mathrm{x} 2$

Secara Parsial, Variabel Kualitas Pelayanan dan Variabel Promosi berpengaruh positif dan signifikan, artinya dapat disimpulkan bahwa ketika kualitas pelayanan ditingkatkan, maka pembelian akan meningkat.

Model Summary

\begin{tabular}{|c|c|c|c|c|}
\hline Model & $\mathrm{R}$ & $\begin{array}{c}\mathrm{R} \\
\text { Square }\end{array}$ & $\begin{array}{c}\text { Adjusted } \mathrm{R} \\
\text { Square }\end{array}$ & $\begin{array}{c}\text { Std. Error of } \\
\text { the Estimate }\end{array}$ \\
\hline 1 &, 58 &, 34 &, 32 & 1,14 \\
\hline
\end{tabular}

Sumber: Data diolah (2020)

Tabel model summary terlihat nilai Nilai $\mathrm{R}$ Square dengan nilai sebesar 0,34 adalah koefisien korelasi yang menunjukkan tingkat hubungan antara Kualitas Pelayanan $\left(\mathrm{X}_{1}\right)$ dan Promosi $\left(\mathrm{X}_{2}\right)$ terhadap variabel Keputusan Pembelian (Y) sebesar $34 \%$. Yang artinya model penelitian mampu menjelaskan dari perubahan Keputusan Pembelian sebesar $34 \%$. Sedangkan sisanya $(100 \%-34 \%=66 \%)$ dijelaskan oleh faktor lain

Uji F

\begin{tabular}{|c|c|c|c|c|c|c|}
\hline Mode & & $\begin{array}{l}\text { Sum of } \\
\text { Squares }\end{array}$ & Df & $\begin{array}{c}\text { Mean } \\
\text { Square }\end{array}$ & $F$ & Sig. \\
\hline \multirow{3}{*}{1} & Regression & 63,43 & 2 & 31,72 & 24,44 & .000 \\
\hline & Residual & 124,57 & 96 & 1,30 & & \\
\hline & Total & 188,00 & 98 & & & \\
\hline
\end{tabular}

Sumber: Data diolah (2020)

Dari Uji Anova atau $\mathrm{F}$ test, didapat tingkat signifikansi nilai sig. $=0.000$ (Nilai Sig. $<0,05$ ) Karena nilai sig 0,000 lebih kecil dari 0,05 maka dapat disimpulkan Variabel Xl dan Berpengaruh signifikan secara bersama-sama terhadap variabel Y.

Uji t Digunakan untuk menghitung signifikasi pengaruh secara parsial atau dari masing-masing variabel X terhadap Y.

a. Variabel Kualitas Pelayanan (Xl) didapatkan nilai sig. $=0.000$ (Nilai Sig. $>0,05)$ lebih kecil dari 0,05 , yang artinya secara parsial variabel Kualitas Pelayanan (Xl) berpengaruh signifikan terhadap variabel terikat Keputusan Pembelian

b. Variabel Promosi (X2) didapatkan nilai sig. $=0.000$ (Nilai Sig $<0,05)$ lebih kecil dari 0,05 , yang artinya secara parsial variabel Promosi (X2) berpengaruh signifikan terhadap variabel terikat Keputusan Pembelian.

Pengujian variabel bebas yang dominan mempengaruhi variabel terikat dalam satu model regresi linier berganda dengan menggunakan nilai Standardized Coefficients Beta. Dengan 
penentuan hasil, semakin tinggi nilai Beta, maka semakin besar pengaruhnya terhadap variabel terikat. Berdasarkan tabel diatas ,dapat diketahui bahwa variabel Kualitas Pelayanan (XI) memiliki nilai standarized coefficient sebesar 0,40 , variabel Promosi (X2) memiliki nilai 0,35 , dengan demikian variabel yang berpengaruh dominan terhadap Keputusan Pembelian adalah variabel Kualitas Pelayanan (X2)

\section{Pembahasan}

Pada penelitian kali ini, ditemukan bahwa ketika semakin tinggi kualitas pelayanan maka akan semakin tinggi pula keputusan pembelian, karena pada hasil uji regresi linier berganda menunjukan bahwa kualitas pelayanan terbukti berpengaruh signifikan terhadap keputusan pembelian. Yang direpresentasikan oleh beberapa indicator yaitu :

Indikator pertama bukti fisik (tangible) pada variabel kualitas pelayanan pada penelitian kali ini meraih skor rata-rata yang tergolong baik, yang artinya bukti fisik ini berkontribusi tinggi bagi penilaian pelanggan karena faktor in; menjadi kesan pertama bagi para pengunjung pada Gofood Festival ketersediaan fasilitas yang memadai dan kebersihan fasilitas merupakan poin yang sangat penting bagi bisnis kuliner seperti Gofood Festival ini. Penataan letak yang baik, kebersihan dan kenyamanan konsumen yang dikelola dengan baik akan menarik para konsumen untuk melakukan pembelian pada Gofood Festival.

Indikator Kehandalan (reability) meraih skor rata - rata jawaban yang sedikit lebih rendah dibanding indikator bukti fisik namun masih tergolong baik, hal ini bisa terjadi karena pada indikator ini menyangkut kepuasan konsumen atas pelayanan langsung yang diberikan oleh pelayan atau pegawai Gofood Festival itu sendiri kepada para konsumen.

Indikator Ketanggapan (responsive) meraih skor rata-rata jawaban yang sama dengan indikator kehandalan yaitu tergolong baik. Hal ini bisa terjadi karena pada saat pelanggan datang berkunjung dan melakukan pembelian atau pemesanan pihak GoFood Festival seharusnya bisa lebih maksimal dalam memberikan respon atau konfirmasi dengan cepat segera ketika pelanggan melakukan pemesanan makanan.
Pihak GoFood Festival sebaiknya memberitahukan berapa lama makanan tersebut bisa dihidangkan, dan melayani setiap permintaan pelanggan dengan ramah. Indikator Jaminan (assurance) meraih skor rata-rata terendah namun masih tergolong baik pada variabel kualitas pelayanan. Artinya terdapat pelanggan yang merasa kurang puas terhadap jaminan yang diberikan oleh pihak Gofood Festival. Jaminan yang dimaksud adalah jaminan dalam hal keamanan dan kenyamanan ketika konsumen berada di lingkungan Gofood Festival.

Indikator Empati (empathy) meraih skor rata-rata tertinggi dalam variabel kualitas pelayanan dan tergolong baik artinya indikator ini memberikan pengaruh positif yang paling tinggi terhadap keputusan pembelian. Faktor ini mencakup perhatian dan kesungguhan yang ditunjukkan secara personal oleh pelayan Gofood Festival kepada konsumen. Artinya pihak GoFood Festival sudah memberikan kesungguhan dalam merespon permintaan pelanggan dengan cukup baik dan telah memberikan perhatian dan pelayanan kepada setiap pelanggan tanpa memandang status sosial.

Kemudian pada variabel promosi terdapat Indikator Periklanan (Advertising) yang meraih Skor rata-rata yang tergolong netral. Hal ini bisa terjadi karena periklananan yang dilakukan oleh pihak Gofood festival kurang gencar dan luas, akibatnya banyak orang yang tidak mengetahui tentang Gofood festival itu sendiri. Periklananan pada dasarnya bertujuan untuk membuat pelanggan mengetahui produk atau layanan apa saja yang ditawarkan oleh sebuah perusahaan dan membuat mereka tertarik untuk membelinya. Promosi yang sudah dilakukan oleh Gofood Festival seharusnya bisa lebih diperbaiki lagi dan bisa menjangkau konsumen yang lebih luas agar semakin banyak orang yang mendapatkan pemberitahuan tentang promosi GoFood Festival. Indikator Promosi Penjualan (sales promotion) meraih Skor rata-rata yang tergolong netral. Artinya terdapat konsumen yang tidak merasa tertarik terhadap promosi penjualan yang ada pada Gofood Festival. Promosi penjualan yang dimaksud bisa berupa voucher potongan harga, dan penawaran khusus pada periode tertentu seperti( Hari Libur, Hari Nasional dan Hari penting Iainnya ) dengan promosi yang dilakukan 
pihak GoFood Festival diharapkan dapat mendorong pelanggan melakukan pembelian sesegera mungkin. Promosi penjualan yang telah dilakukan oleh Gofood Festival seharusnya bisa lebih ditingkatkan lagi agar menarik lebih banyak calon konsumen dan meningkatkan keputusan pembelian bagi konsumen yang sudah pernah berkunjung di Gofood Festival

\section{Kesimpulan}

Variabel penelitian terdiri dari Kualitas pelayanan, Promosi dan Keputusan Pembelian, berdasarkan hasil penelitian dan juga pembahasan maka kesimpulan pada penelitian ini sebagai berikut

1. Kualitas pelayanan dan Promosi berpengaruh signifikan secara simultan terhadap keputusan pembelian pada Merchant GoFood Festival Duta Mall Banjarmasin. Kualitas Pelayanan yang baik dan Promosi yang optimal secara langsung meningkatkan keputusan pembelian pada Merchant GoFood Festival Duta Mall Banjarmasin.

2. Kualitas Pelayanan berpengaruh signifikan secara parsial terhadap keputusan pembelian pada Merchant GoFood Festival Duta Mall Banjarmasin. Kualitas Pelayanan yang baik secara langsung meningkatkan keputusan pembelian pada Merchant GoFood Festival Duta Mall Banjarmasin.

3. Promosi berpengaruh signifikan secara parsial terhadap keputusan pernbelian pada Merchant GoFood Festival Duta Mall Banjarmasin. Strategi Promosi yang tepat akan secara langsung meningkatkan keputusan pembelian pada Merchant GoFood Festival Duta Mall Banjarmasin.

4. Variabel Kualitas Pelayanan adalah variabel yang berpengaruh dominan terhadap keputusan pembelian pada Merchant GoFood Festival Duta Mall Banjarmasin.

\section{Saran}

1. GoFood Festival Banjarmasin dalam melayani konsumen hendaknya lebih memperhatikan secara detail apa saja yang dibutuhkan dan diinginkan konsumen yang datang berkunjung agar mereka merasa diistimewakan dan tidak merasa kecewa, dan lebih memperhatikan dalam hal kenyamanan khususnya toilet dan tempat makan yang bersih agar meningkatkan kenyamanan bagi para konsumen yang berbelanja di GoFood Festival Banjarmasin.

2. GoFood Festival Banjarmasin diharapkan melakukan promosi yang lebih gencar lagi di berbagai media agar lebih banyak orang yang mengetahui keberadaan dan produk yang ditawarkan oleh Gofood Festival. Dan promosi yang disebarkan sebaiknya bisa lebih menarik lagi agar konsumen lebih tertarik dan segera berbelanja di GoFood Festival Banjarmasin.

3. Untuk penelitian mendatang sebaiknya dapat menggunakan variabel independen yang Iainnya yang dapat mempengaruhi keputusan pembelian pada Merchant GoFood Festival Duta Mall Banjarmasin. Penelitian yang selanjutnya agar tidak hanya menggunakan alat kuesioner saja untuk mendapatkan data namun juga dengan metodemetode wawancara secara lebih dalam agar dapat memperoleh data yang lebih rinci.

\section{DAFTAR PUSTAKA}

Aditya dwi nugraha, 2014 :20, Analisis Strategi Pemasaran Restoran Agricafedi Kota Bogor

Alfi, Andayani, 2016, Pengaruh Kualitas Pelayanan (Service Quality) Terhadap Kepuasan Pelanggan Pt. Sucofindo Batam

Assauri, S. Manajemen Pemasaran, Jakarta: PT Raja Grafindo Persada, 2015 Dendi Sumawan, 2015 Analisis Pengaruh Promosi, Harga, Dan Lokasi Terhadap Kepuasan Pelanggan Pada Soto Kudus Kauman, Pondok Cabe Kota Tanggerang Selatan

Danang dan Sunyoto, 2013 Teori Kuesioner dan Analisis Data, Yogyakarta: Graha llmu,

Dwiastuti. Dkk, 2013, ilmu Perilaku Konsumen. Malang. UB Press

https://kumparan.com/kumparanfood/go-foodfestival-tanda-bukti-kepedulian-go-jekterhadap-umkm diakses pada 03 Januari 2020

https://www.gojek.com/ diakses pada 18 Januari $\underline{2020}$

https://www.republika.co.id/berita/gayahidup/trend/18/11/10/phystg366-tujuh-halseru-di-instamarket-gofood-festival diakses pada 03 Januari 2020 
Huda, Ahmad Samsul dan Ida Farida, 2014. Pengaruh Pelayanan, Promosi, Dan Lokasi Terhadap Kepuasan Konsumen Toko Joko Elektronik Di Path Jurnal Jurusar, Manajemen Fakultas Ekonomi Dan Bisnis Universitas Dian Nuswantoro.

Indra Wahyu Dianto, 2013, Analisis Kepuasan Konsumen Waroeng Steak \& Shake Jl. Cendrawasih No. 30 Yogyakarta

Jefry F.T,. Soegotodan Loindong, 2014, Pengaruh Kualitas Produk, Harga Dan Lokasi, Terhadap Kepuasan Konsumen Pada Warung-Warung Makan Lamongan di kota Manado. Jurnal EMBA. Fakultas Ekonomi dan Bisnis Universitas Sam Ratulangi Manado. Vol.2 No.3 September 2014

Kotler, dan Keller, 2012, Manajemen Pernasaran. Edisi 12, Jakarta: Erlangga

Kotler. P, 2012, Manajemen Pemasaran : Analisis, Perencanaan, Implementasi dan Pengendalian, Edisi ke-2, Penerbit Erlangga,

Pongoh, M,. E, 2013, Kualitas Pelayanan, Kualitas Produk Dan Harga Pengaruhnya Terhadap Loyalitas Pelanggan Kartu As Telkomsel Di Kota Manado. Jurnal EMBA, Vol 1 : Hal. 85 - 95

Rachmawati Setyaningsih, 2018, Analisis FaktorFaktor Yang Mempengaruhi Pemanfaatan Go-Food (Studi Kasus Pada Mahasiswa Uii)

Ria Anggreani, 2017, Pengaruh Lokasi, Promosi Dan Kualitas Pelayanan Terhadap Kepuasan Konsumen Vanilla Café Tulungagung

Sistaningrum, 2012. Manajemen Penjualan Produk (Penerbit Kanisius, Yogyakarta)

Suci Wulan Sari, 2015, Kepuasan Konsumen Terhadap Kualitas Pelayanan Di Ndalem Ngabean Resto

Sugiyono, 2012, Metode Penelitian Kuantitatif, Kualitatif dan $R \& D$. Bandung : Alfabeta

Sujarweni, Wiratna, 2014, Metodologi Penelitian, Edisi Per-tama. Yogyakarta : SPUTAKABARUPREES.

Swastha dan Irawan, 2010, Manajemen Pemasaran Modern, Liberty, Yogyakarta.

Tjahjaningsih Endang, 2013. Pengaruh Citra Dan Promosi Terhadap Kepuasan
Pelanggan Setta Dampaknya Terhadap Loyalitas Pelanggan ( Studi Pada Pelanggan Supermarket Carrefor Di Semarang ). Jurnal Fakultas Ekonomi Universitas Stikubank

Tjiptono, 2012, Strategi pemasaran, Edisi Ill. Andi, Yogyakarta

Utami, dan Oetomo, 2015. Pengaruh Kualitas Produk, Pelayanan, Harga, dan Lokasi terhadap Loyalitas dengan Kepuasan 